\title{
FESTIVAL VISITORS' EMOTION AND ITS RESPONSE TO THE ENVIRONMENT
}

\author{
Jenny (Jiyeon) Lee, University of New South Wales, Australia
}

\begin{abstract}
The purpose of this paper is to investigate how environmental perceptions elicit different sets of emotions and these emotions in turn influence festival visitors' post-visit evaluation. The present study study adopted the Mehrabian-Russell (M-R) model in environmental psychology in order to better explain how visitors react to the festival physical and social environment. Data were collected from festival goers using an onsite and post-visit survey in 2008 at three community-based festivals in Texas.

The study results demonstrated that certain aspects of festival atmospherics engendered moderate to strong positive emotions and indirectly affecting overall satisfaction. Specifically, loving and joyful feelings elicited through uniquely themed and diverse activities and entertainment along with quality service delivery were associated with generating visitors' satisfying experiences at festivals. The findings of the study have theoretical an practical implications. For practice, the study offers some guidance for festival organizers to create positive emotion-inducing atmospherics, which positively influences visitors' overall satisfaction. For theory, this investigation contributes to furthering our understanding of festival visitors' post-vist behaviors by confirming the proposed model within the M-R framework.
\end{abstract}

References available upon request. 